\title{
Vegetation Succession and Environmental Conditions following Catastrophic Lake Drainage in Old Crow Flats, Yukon
}

\author{
Trevor C. Lantz ${ }^{1}$
}

(Received 20 June 2016; accepted in revised form 9 January 2017)

\begin{abstract}
Increases in the frequency and magnitude of disturbances associated with the thawing of ice-rich permafrost highlight the need to understand long-term vegetation succession in permafrost environments. This study uses field sampling and remote sensing to explore vegetation development and soil conditions following catastrophic lake drainage in Old Crow Flats (OCF). The data presented show that vegetation on drained lake basins in OCF is characterized by two distinct assemblages: tall willow stands and sedge swards. Field sampling indicates that these alternative successional trajectories result from variation in soil moisture following drainage. Increased willow mortality on older drained basins suggests that intraspecific competition drives self-thinning in shrub thickets. This finding, combined with data from paleoecological studies and contemporary vegetation in $\mathrm{OCF}$, suggests that willow stands on drained lake basins are seral communities. These results also indicate that the increase in number of catastrophic drainages that occurred between 1972 and 2010 will alter regional vegetation in ways that affect wildlife habitat, permafrost conditions, and local hydrology.
\end{abstract}

Key words: Subarctic; thermokarst; climate change; shrubs; disturbance; succession

RÉSUMÉ. L'accroissement de la fréquence et de l'ampleur des perturbations liées au dégel du pergélisol à forte teneur en glace fait ressortir la nécessité de comprendre la succession de la végétation à long terme en milieu de pergélisol. Grâce à des travaux d'échantillonnage sur le terrain et à des données obtenues par télédétection, cette étude explore le développement de la végétation et les conditions du sol suivant le drainage catastrophique du lac de la plaine Old Crows (POC). Selon les données obtenues, la végétation des bassins lacustres drainés de la POC relève de deux assemblages distincts : des peuplements de grands saules et des peuplements de foin plat. L'échantillonnage sur le terrain indique que ces trajectoires de succession différents découlent de la variation de l'humidité du sol après le drainage. Le taux de mortalité accru des saules dans les bassins drainés plus anciens suggère que la compétition intraspécifique entraîne l'autoréduction dans les taillis d'arbustes. Alliée aux données émanant d’études paléoécologiques et aux données sur la végétation contemporaine de la POC, cette observation suggère que les peuplements de saules des bassins lacustres drainés sont des communautés de succession. Ces résultats indiquent aussi que l'augmentation du nombre de drainages catastrophiques qui se sont produits entre 1972 et 2010 aura pour effet d'altérer la végétation régionale, ce qui aura des incidences sur l'habitat de la faune, les conditions du pergélisol et l'hydrologie de la région.

Mots clés : subarctique; thermokarst; changement climatique; arbustes; perturbation; succession

Traduit pour la revue Arctic par Nicole Giguère.

\section{INTRODUCTION}

Growing evidence indicates that the frequency and magnitude of natural disturbances at high latitudes are increasing. Subarctic wildfires have become larger and more frequent (Kasischke and Turetsky, 2006), the area burned by tundra fire is increasing (Higuera et al., 2008; Rocha et al., 2012), and disturbances related to thawing permafrost (thermokarst) show accelerated growth rates and increased frequency in many regions (Lewkowicz and Harris, 2005; Kokelj et al., 2013; Lantz and Turner, 2015; Segal et al., 2016). Recent studies also indicate that increased flooding and salinization of coastal areas is affecting plant communities in Arctic terrestrial ecosystems
(Arp et al., 2010; Kokelj et al., 2012; Lantz et al., 2015). It is anticipated that continued development in the North will also increase the area of tundra affected by disturbance (Holroyd and Retzer, 2005; Burn and Kokelj, 2009).

Field studies show that northern ecosystems exhibit a range of recovery trajectories following disturbance (Walker et al., 1987). Disturbances such as tundra fire and seismic exploration create relatively small and transient changes in vegetation structure and species composition (Kemper and Macdonald, 2009b; Bret-Harte et al., 2013). Conversely, disturbances like severe Subarctic fire and retrogressive thaw slumping, which remove vegetation cover and soil organics, can facilitate the development and persistence of alternative successional trajectories (Lantz

\footnotetext{
${ }^{1}$ School of Environmental Studies, University of Victoria, PO Box 1700 STN CSC, Victoria, British Columbia V8W 2Y2, Canada; tlantz@uvic.ca

(C) The Arctic Institute of North America
} 
et al., 2009, 2010). In Arctic coastal environments, high soil salinity following storm surges or the thawing of saltrich marine sediments can completely inhibit vegetation recovery (Handa et al., 2002; Lantz et al., 2015). Since vegetation structure exerts strong controls on ecological processes (Chapin et al., 2000; Lantz et al., 2013), additional case studies are required to better understand successional trajectories in Arctic and Subarctic environments.

In permafrost environments, thermo-mechanical erosion of near-surface ground ice can lead to complete or partial lake drainage (Mackay, 1988; Hinkel et al., 2003). These catastrophic drainages typically occur rapidly (within 1-2 days) and create terrestrial surfaces that persist for millennia (Hinkel et al., 2003; Jorgenson and Shur, 2007). In many regions, lake drainage throughout the Holocene has created landscapes covered by drained basins of a variety of ages (Hinkel et al., 2003; Lauriol et al., 2009). Research combining historical photos and satellite imagery shows that the lake-rich landscapes in some regions are changing. In areas of discontinuous permafrost, reductions in the area and number of lakes have been observed (Smith et al., 2005; Riordan et al., 2006). In areas of continuous permafrost, recent studies have revealed both decreases (Labrecque et al., 2009; Jones et al., 2011; Lantz and Turner, 2015) and increases (Smith et al., 2005; Jones et al., 2011) in the number and area of lakes. Another recent study in continuous permafrost showed that the number of catastrophic drainages in the Tuktoyaktuk Coastlands has decreased in recent decades (Marsh et al., 2009).

Considerable effort has been focused on understanding abiotic changes following lake drainage in the Low Arctic (Mackay and Burn, 2002a, b), and Ovenden (1986) examined plant communities seven years after the experimental drainage of a lake in the Tuktoyaktuk Coastlands. However, no published research has explored decadal-scale vegetation development following catastrophic drainage. In this paper, field sampling and remote sensing are used to explore vegetation development and soil conditions following catastrophic drainage in the Old Crow Flats, Yukon.

\section{METHODS}

\section{Study Area}

The Old Crow Flats (OCF) is a low-lying ecosystem with its southern boundary located approximately $25 \mathrm{~km}$ north of the community of Old Crow (Fig. 1). The climate of the OCF is characterized by long, cold winters (mean daily temperature in January $=-29.2^{\circ} \mathrm{C}$ ) and short, warm summers (mean daily temperature in July $=14.6^{\circ} \mathrm{C}$ ). Mean annual precipitation in Old Crow is $279 \mathrm{~mm}$, approximately half of which falls as snow (Environment Canada, 2016). The boundaries of the OCF correspond roughly to the extent of a large glacial lake that was present in this area at the end of the Wisconsinan glaciation (Zazula et al., 2004).

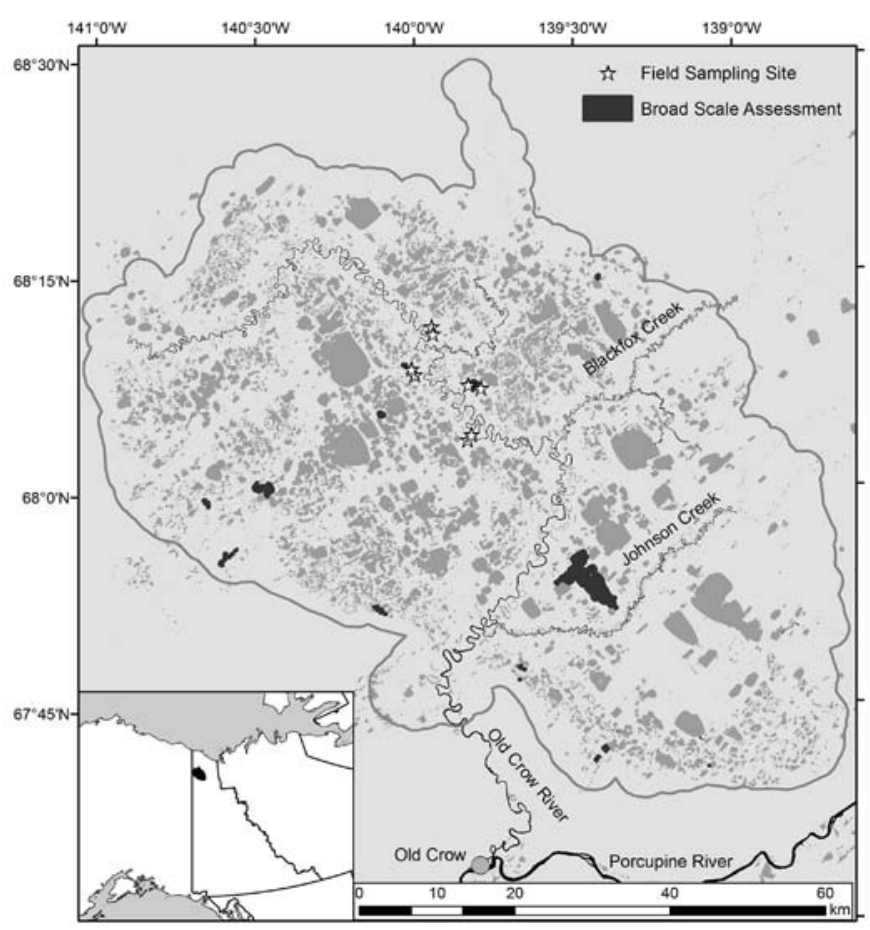

FIG. 1. Map of the study area in the Old Crow Flats. Lakes are shown in light grey and major drainages as solid black lines. Sites visited in the field $(\mathrm{n}=8)$ are shown as stars, and lakes included in the broad-scale assessment $(n=21)$ are shown in dark grey. The grey line defines the area used for land cover classification. The inset map at the bottom left shows the location of the study area in northern Canada.

Lakes cover approximately $23 \%$ of this area (Lantz and Turner, 2015), which is bisected by the drainage network of the Old Crow River (Fig. 1). Abundant terrestrial, riparian, and wetland environments in the OCF support large populations of fish, moose, muskrat, and migratory birds (Smith et al., 2004). The terrestrial surface of the OCF is dominated by a mix of upright shrub tundra (Betula spp., Salix spp.) and dwarf shrub tundra (Ledum decumbens (Ait.) Lodd., Vaccinium spp.). Sphagnum-dominated peatlands are found in low-lying zones across the study area, and spruce woodlands dominate sites adjacent to major rivers, creeks, and some south-facing slopes. Shallow lakes that host an abundance of aquatic macrophytes (Nuphar polysepalum Engelm., Calla palustris L., Pogomogenon spp.) are also common in the study area (Smith et al., 2004).

The OCF is part of the traditional Territory of the Vuntut Gwitchin First Nation, who refer to this area in Gwich'in as Van Tat ('land of many lakes'). Vuntut Gwich'in have used this culturally significant ecosystem for subsistence for thousands of years (Vuntut Gwitchin First Nation and Smith, 2009). In 1982, the OCF was designated a Wetland of International Importance under the Ramsar Convention. A large portion of the OCF is within the boundaries of Vuntut National Park, and the remainder is included in a conservation agreement between the Yukon and Vuntut Gwichin governments (Parks Canada et al., 2010). Drained lake basins ranging in age from less than 10 to more than 11000 years old are common in the OCF, indicating that 
drainage has occurred throughout the Holocene (Ovenden, 1986; Lauriol et al., 2009; Lantz and Turner, 2015). In the last several decades, Vuntut Gwich'in observers have reported changes in the vegetation of the OCF and noted an increase in the number of lakes draining and drying (Wolfe et al., 2011). An analysis of air photos and satellite imagery confirms that catastrophic lake drainage was four to five times more frequent between 1972 and 2010 than between 1951 and 1972 (Lantz and Turner, 2015).

\section{Field Sampling}

To characterize plant succession and environmental conditions following catastrophic lake drainage, detailed field surveys were conducted at five drained lake basins and three reference sites: a woodland and an upright shrubland underlain by mineral soil, and a dwarf shrubland underlain by organic soil (Fig. 1). Reference sites were selected to reflect variation in the dominant terrestrial vegetation at sites not affected by disturbance over the last several hundred years. Catastrophically drained lake basins of known age were selected using georeferenced air photos from 1951 and 1972 and Landsat images (1973-2010) from the USGS archive (Lantz and Turner, 2015). Drainage dates obtained using remote sensing were verified by collecting discs from the largest trees and shrubs present in each former basin. These cross sections were sanded, and growth rings were counted using a dissecting microscope.

At each drained basin, four transects were established: two extending from the former shoreline towards the center of the basin, and two located on a random azimuth in a more central portion of the former lake. At each reference site, two transects were established within homogenous terrain. All transects were $80 \mathrm{~m}$ long and included nine sample points positioned at $10 \mathrm{~m}$ intervals. At each point, plant community composition was measured by visually estimating percent cover in quadrats. For tall shrubs, namely Salix spp., Betula spp., and Alnus crispa (Drylander ex. Ait.) Pursh, cover was estimated using $5 \mathrm{~m}^{2}$ quadrats, each centred on a sample point. For dwarf shrubs, herbs, forbs, mosses, and lichens, cover was estimated using $0.5 \mathrm{~m}^{2}$ quadrats randomly nested within the $5 \mathrm{~m}^{2}$ plot. Vascular plant nomenclature used throughout this paper follows Cody (2000). Within each $5 \mathrm{~m}^{2}$ quadrat, the number of tall shrub stems (living vs. dead) was counted and their diameter and height were recorded.

Along each transect several abiotic variables were also measured every $10 \mathrm{~m}$. In late August 2009, thaw depth was measured by pushing a graduated steel probe into the ground to depth of refusal. Soil moisture in the upper soil horizon $(0-25 \mathrm{~cm})$ was described qualitatively by digging a small hole $(\sim 25 \times 25 \mathrm{~cm})$ and using the moisture codes $(1-10)$ described by Smith et al. (2007). The thickness of the soil organic layer was measured by using a trowel to expose the interface between mineral and organic horizons inside this hole.

\section{Statistical Analysis}

To explore differences in community composition among drained basins and reference sites, the statistical software PRIMER was used to conduct two analyses of vascular plant abundance data (Clarke and Gorley, 2001). The first analysis included all sample sites and used PRIMER to perform a non-metric multidimensional scaling (NMDS) ordination of a Bray-Curtis distance matrix calculated from the percent cover data. Subsequently, ANOSIM (Analysis of Similarities) was used to test whether species composition differed among sites. The $\mathrm{R}_{A N O S I M}$ statistic expresses the similarity between groups using a range of zero to one (Clarke and Gorley, 2001). The significance of the $\mathrm{R}_{\text {ANOSIM }}$ statistic was calculated by performing 9999 randomizations of the original data. To identify the species making the largest contribution to differences between sites, the SIMPER function in PRIMER was used to calculate the percent contribution of each species and species group to the Bray-Curtis dissimilarities among sites (Clarke and Gorley, 2001).

The second multivariate analysis, a hierarchical cluster analysis using PRIMER and the Bray-Curtis distance matrix, focused on drained lake basins only. This limitation facilitated more detailed comparisons of community composition and allowed the assessment of differences in successional trajectories following lake drainage. To assess the species composition of clusters, a $40 \%$ similarity threshold was used to define a small number of homogenous groups, which were compared using the SIMPER procedure. In this analysis, the group average option was used to create final clusters. The relationship between these groups and individual basins was also explored visually using NMDS ordination. To examine correlations between community structure and the abiotic parameters measured at drained lake basins, the ENVFIT function in the VEGAN package for $\mathrm{R}$ was used to evaluate relations among environmental variables and NMDS scores (R Development Core Team, 2008). The matrix of normalized environmental variables used included soil moisture, thaw depth, percent bare ground, organic layer thickness, litter layer thickness, canopy height, and living and dead shrub stem density. The significance of correlations between abiotic variables and community composition was assessed using 9999 random permutations of the data (R Development Core Team, 2008). In both NMDS analyses, PRIMER was set to repeat analysis 20 times and select the best two-dimensional representation of the original distance matrix (i.e., least stress) (Legendre and Legendre, 1998). The percent cover data used in both analyses was $\log (1+\mathrm{x})$ transformed to reduce noise and ordination stress.

\section{Broad-scale Pattern}

The complex logistics associated with accessing multiple sites in the OCF (by float plane, canoe, and 
hiking) restricted the number of sites where detailed data on vegetation structure and composition could be collected. To determine whether these differences are consistent with variation across the study area, landscape-scale variability in the vegetation on drained lake basins was characterized using data on the timing of lake drainage (Lantz and Turner, 2015) and a land-cover classification derived from an object-oriented classification of a SPOT-5 satellite image. This classification had overall accuracy of $83 \%$ and is described in more detail in Clarke et al. (2017). Together, these data were used to calculate the percent cover of the dominant vegetation on drained lake basins in two age classes: 1) lakes that drained between 1975 and 1992 $(\mathrm{n}=12)$ and 2) lakes that drained between 1997 and 2003 $(\mathrm{n}=9)$.

\section{RESULTS}

The drained lake basins surveyed in the field had vegetation structure distinct from that of the surrounding landscape. Drained lake basins between 12 and 43 years old were dominated by willows twice the height of the vegetation found at reference sites (Fig. 2). Only the oldest basin ( $\sim 83$ years) had a shrub canopy comparable to that of the reference shrub tundra site sampled (Fig. 2A). Stem density was also elevated on drained basins of intermediate age. It was highest at basin 3, where the number of live stems was close to double the mean density at the reference shrub tundra site (Fig. 2B). Drained lake basins more than 30 years old also had higher densities of dead stems than reference sites and younger drained basins (Fig. 2C).

Field sampling also revealed differences among sites in organic layer thickness and thaw depth. Drained basins 1 to 4 all had shallower organic horizons than all the reference sites visited. In general, organic layer thickness increased with drained basin age, but approached levels found at reference sites $(13-20 \mathrm{~cm})$ only on basin 5 $(17 \mathrm{~cm})$, the oldest basin sampled (Fig. 3A). Mean thaw depth generally declined with basin age and was generally higher at drained basins $(38-62 \mathrm{~cm})$ than at reference sites (29-34 cm; Fig. 3B). None of the drained lake basins visited in the field exhibited depressed margins as described by Roy-Léveillée and Burn (2016) at three older drained basins in the southeastern part of the study area.

Plant community composition also differed among sites (Tables 1 and 2). The youngest drained lake basin was dominated by moss, Eriophorum russeolum Fries, Carex aquatilis Wahlenb., and Senecio congestus (R. Br.) DC. and showed virtually no compositional overlap with other sites (Figs. 4 and 5; Tables 1 and 2). Drained basins 2, 3, and 4 were all dominated by Salix spp. and Equisetum spp. and exhibited considerable overlap with each other, but were distinct from reference sites. Basin 5, the oldest drained basin sampled ( $\sim 83$ years), was dominated by moss, Salix spp., Carex aquatilis, and Ledum decumbens. This drained lake basin was distinct from the youngest drained
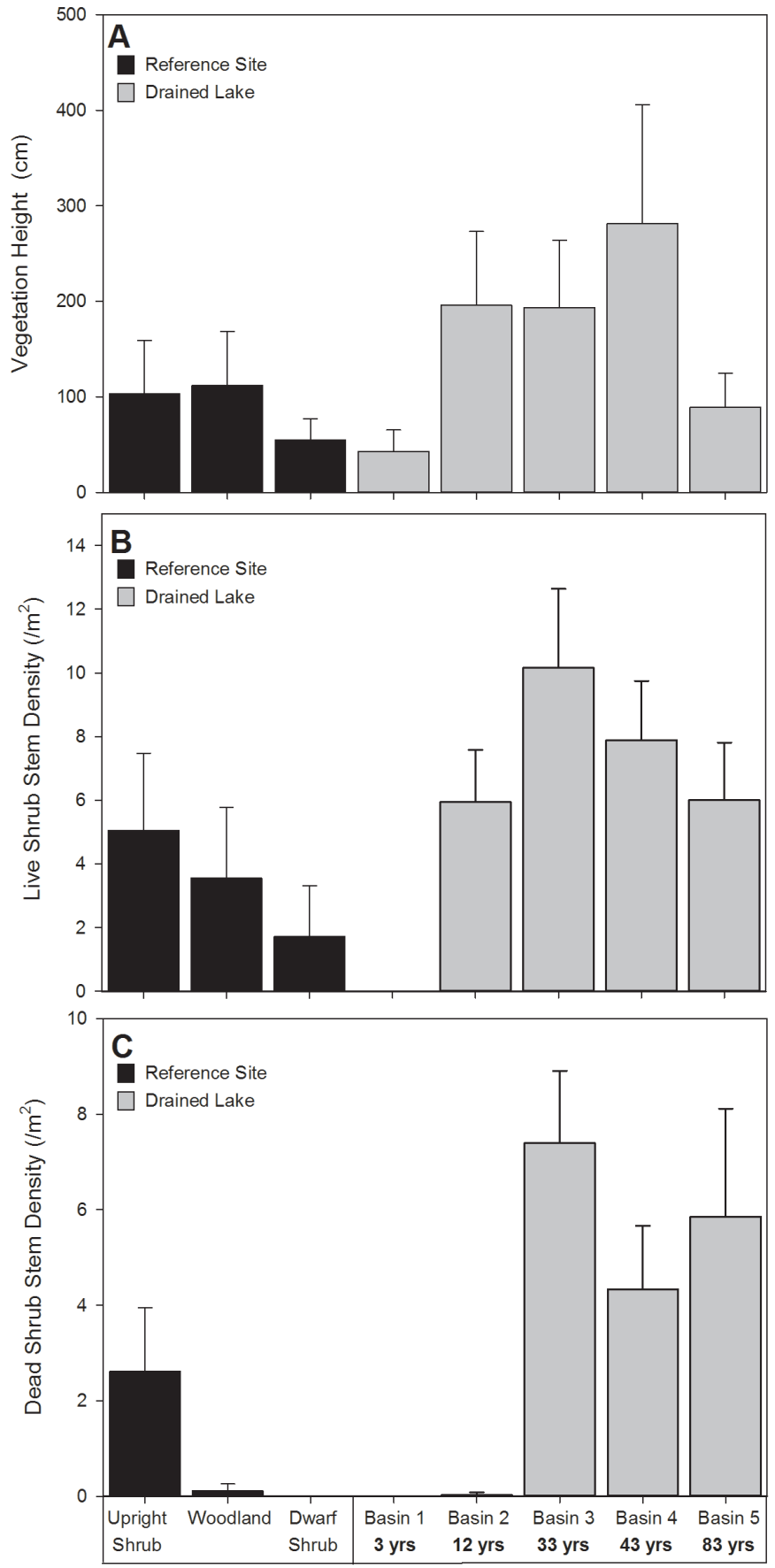

FIG. 2. Vegetation structure at the sample sites in the Old Crow Flats. Bars show means for (A) vegetation height, (B) live shrub stem density, and (C) dead shrub stem density. Error bars show the standard deviation. Black bars show undisturbed sites, and grey bars indicate drained lake basins.

lake basin, but showed some overlap with reference sites. Upright and dwarf shrub sites also exhibited some overlap in species composition, but both were distinct from the woodland site (Figs. 4 and 5; Tables 1 and 2).

The NMDS analysis limited to drained lake basins showed a similar pattern. The youngest and oldest basins had species compositions distinct from each other, and the three basins of intermediate age (basins 2-4) exhibited considerable overlap (Fig. 4B). The CLUSTER analysis of 

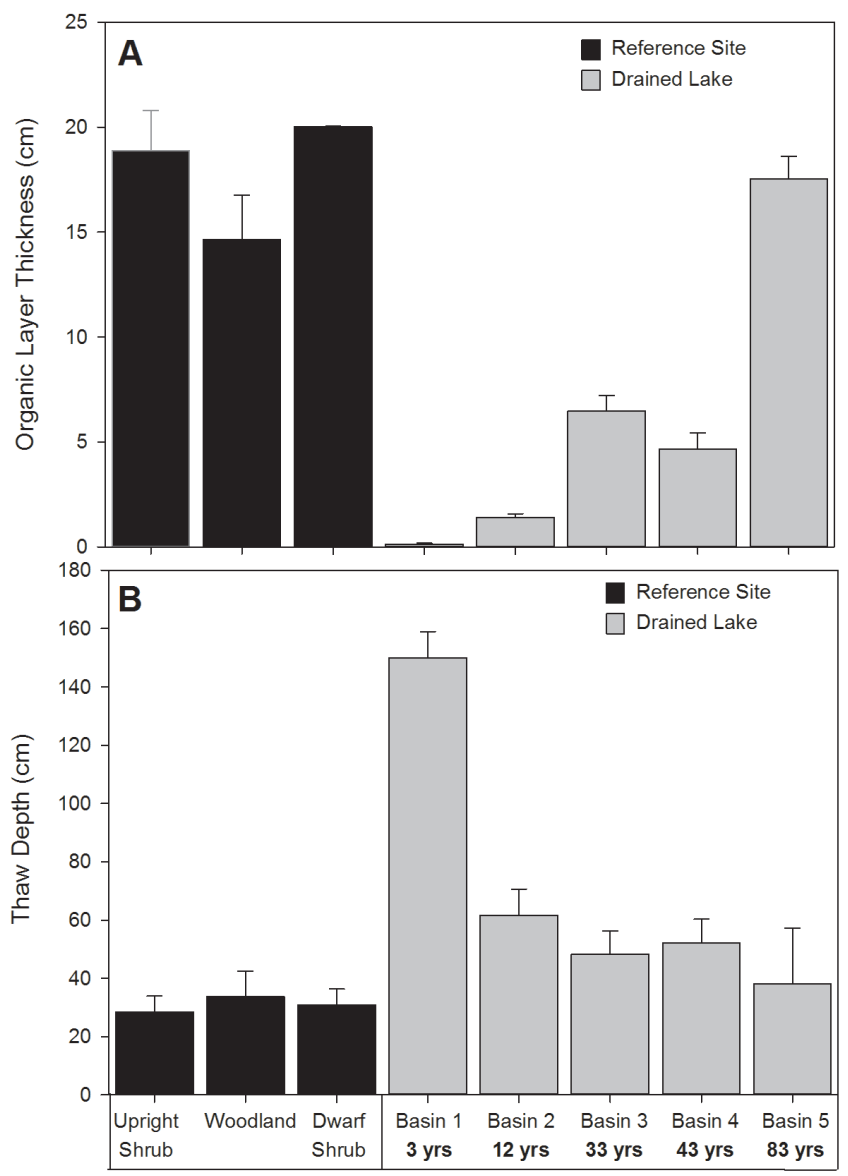

FIG. 3. Soil characteristics at the sample sites in the Old Crow Flats. Bars show means for (A) organic layer thickness, and (B) thaw depth. Error bars show the standard deviations. Black bars show undisturbed sites, and grey bars indicate drained lake basins.

plant abundance data on drained lake basins yielded groups that generally corresponded with the individual basins sampled (Table 3). Cluster C included all the plots sampled in the most recently drained basin and was characterized by an abundance of moss, Eriophorum russeolum, Carex aquatilis, and Senecio congestus (Table 4). Cluster $\mathrm{B}$ included the majority of plots sampled at basins of intermediate age and was typified by an abundance of Salix spp. and Equisetum spp. Cluster A included most of the plots in the oldest drained basin and was characterized by the dominance of moss, Salix spp., Equisetum spp., and Arctostaphylos rubra (Rehd. \& Wils.) Fern. Cluster $\mathrm{D}$ included plots from three of the drained lake basins sampled, which were all dominated by the hydrophilic species Carex aquatilis (Fig. 4B, Table 4). Plots dominated by Carex aquatilis were patchily distributed and were found near basin centers and margins. Community composition at drained lake basins was also significantly correlated with physical conditions. Species composition in basins that had drained more than 10 years prior was associated with shallow thaw depth and more mesic soils. Community structure at the oldest drained basin was correlated with increased organic thickness. The MDS scores of sites
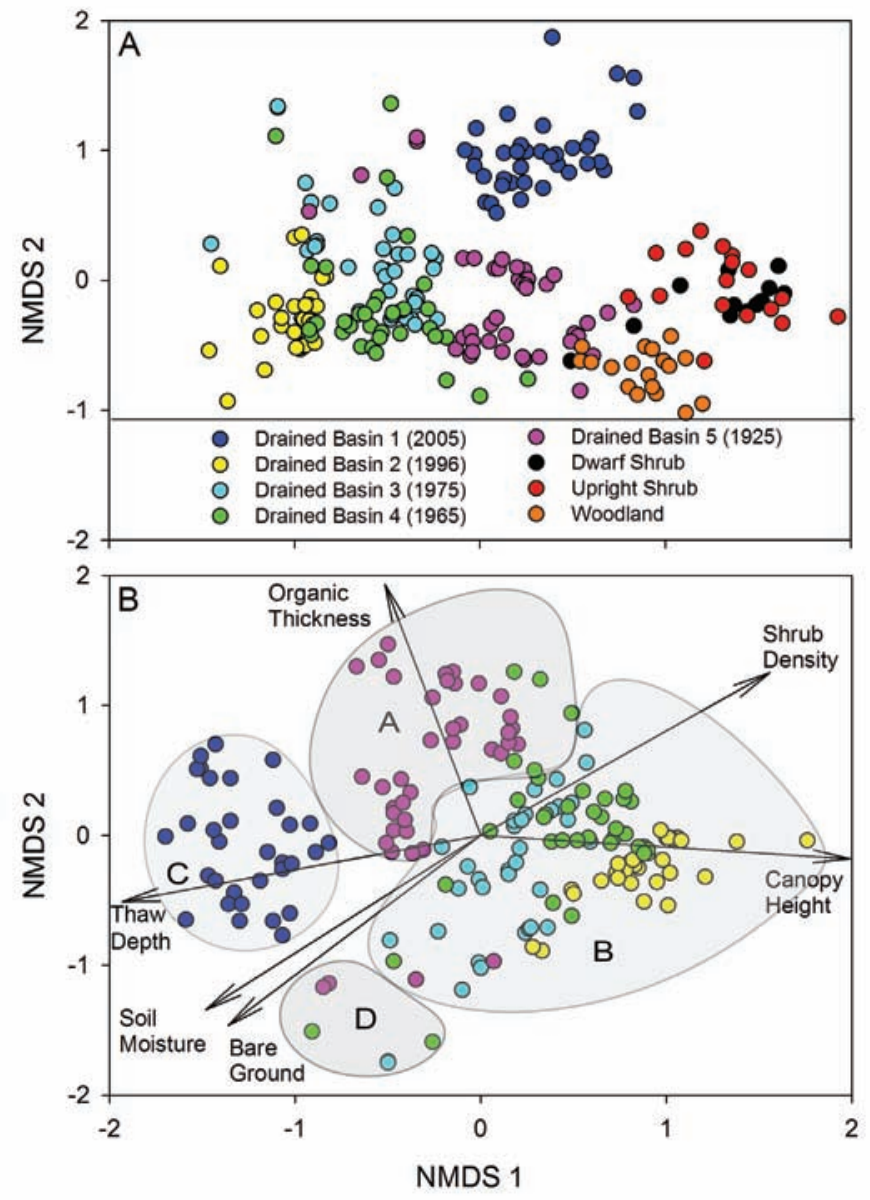

FIG. 4. Non-metric multidimensional scaling (NMDS) ordination of plant community composition based on Bray-Curtis similarity matrices. Results are shown for (A) analysis of all sample sites and (B) analysis of drained basins only. In (B), the grey shaded areas (A-D) show the groups produced by cluster analysis, and the arrows show significant correlations between abiotic variables and NMDS scores.

dominated by Carex aquatilis (cluster D) were strongly correlated with increased soil moisture and the percent cover of bare ground (Fig. 4B).

The vegetation structure encountered at the drained basins visited in the field was similar to the pattern observed at a broader scale. Land-cover data showed that basins that drained between 1997 and 2003 were dominated almost exclusively by a mix of shrub (tall willow) and herbaceous vegetation (sedge sward). Basins where drainage occurred between 1975 and 1992 were also dominated by shrub, but had slightly lower cover of herbaceous vegetation (Figs. 6 and 7).

\section{DISCUSSION}

\section{Short-term Succession}

The data presented here show that catastrophic lake drainage in the Old Crow Flats leads to the development of two vegetation types. At the basin scale, these assemblages 


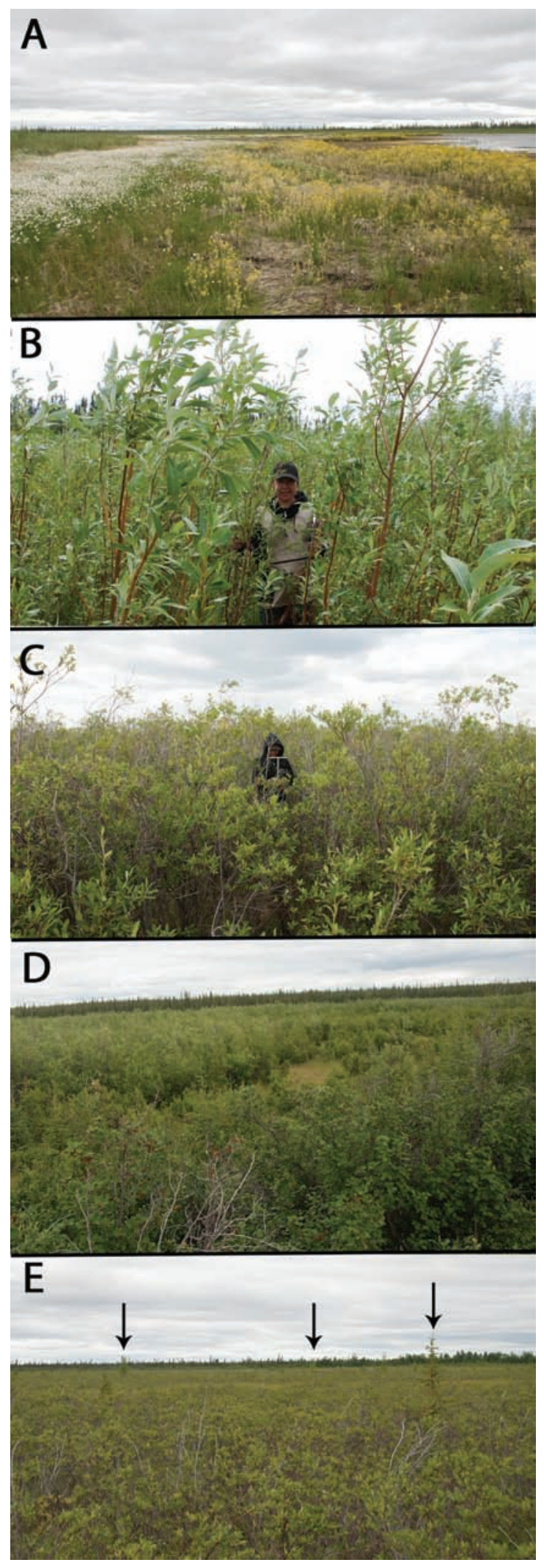

FIG. 5. Photographs of the drained basins sampled in the Old Crow Flats. (A) drained basin 1 ( 3 years old; 68 $7^{\prime} 14^{\prime \prime} \mathrm{N} ; 139^{\circ} 50^{\prime} 21^{\prime \prime} \mathrm{W}$ ), (B) drained basin 2 (12 years old, 68 $8^{\circ} 7^{\prime} 29^{\prime \prime} \mathrm{N}, 139^{\circ} 49^{\prime} 32^{\prime \prime} \mathrm{W}$ ), (C) drained basin 3 (33 years old, $68^{\circ} 8^{\prime} 30^{\prime \prime} \mathrm{N}, 140^{\circ} 1^{\prime} 12^{\prime \prime} \mathrm{W}$ ), (D) drained basin 4 (43 years old, $68^{\circ} 11^{\prime} 21^{\prime \prime}$ $\left.\mathrm{N}, 139^{\circ} 56^{\prime} 48^{\prime \prime} \mathrm{W}\right)$, (E) drained basin 5 ( $\sim 83$ years old, $68^{\circ} 3^{\prime} 43^{\prime \prime} \mathrm{N}, 139^{\circ} 51^{\prime} 10^{\prime \prime}$ W). Note the spruce and birch saplings visible towards the center of basin 5 (arrows). form a mosaic that corresponds to differences in soil moisture across the drained surface. In dry to mesic areas, drainage is followed by the rapid development of dense stands of willow (primarily Salix pulchra and Salix glauca). The majority of the species that colonized the youngest basin we sampled have small seeds (Royal Botanic Gardens, Kew, 2008) and are well adapted to rapid dispersal (Epilobium palustre L., Eriophorum russeolum, Salix spp., Senecio congestus, and Stellaria longipes Goldie). All of these plants are well suited to the environmental conditions on drained surfaces, but the rapid growth of willows (Walker and Chapin, 1986; Cannell et al., 1988) results in the exclusion of most other species. Qualitative field observations made during this project suggest that competitive exclusion by willows can occur very rapidly. At the outset of this project, one of the largest lakes in the study area ( $1223 \mathrm{ha})$ drained catastrophically (Turner et al., 2014). Photographs of the site taken two years after drainage clearly show that willow was already the dominant vegetation over much of the former basin (Fig. 8). Observations in the OCF are consistent with reports that upright shrubs dominate many recently drained lake basins in the Tuktoyaktuk Coastlands (Ovenden, 1986; Mackay and Burn, 2002a). However, these findings differ from field studies on the North Slope of Alaska, which show that early succession on drained lake basins is dominated by hydrophilic graminoids, including Dupontia fisheri R. Br., Eriophorum scheuchzeri Hoppe, and Arctophila fulva (Trin.) Rupr. (Billings and Peterson, 1980; Zona et al., 2010). This difference suggests that variations in local climate and the regional species pool may also alter the direction of succession following catastrophic drainage.

The rapid development of tall shrub thickets has also been observed on retrogressive thaw slumps and following tundra fires that removed surface organics (Lantz et al., 2009, 2010). However, unlike these disturbance sites, drained lake basins are not completely colonized by willow. Broad-scale data on vegetation cover derived from a terrain classification in recently drained basins show that willow thickets on drained lake basins are interspersed with large areas of herbaceous vegetation (Fig. 6). The correlation between sites dominated by Carex aquatilis and high soil moisture indicates that the direction of succession following drainage is determined primarily by soil conditions, with waterlogged sites limiting the establishment of willow and other shrubs that typically thrive after tundra disturbance (Johnstone and Kokelj, 2008; Kemper and Macdonald, 2009a; Lantz et al., 2009, 2010). This explanation is consistent with the pattern seen on oblique aerial photos of lake basins that drained in the last 35 years. These images show that areas of herbaceous vegetation dominated by sedges tend to occur in low-lying parts of drained lake basins (Fig. 7). Macrofossils of Salix spp. and Carex spp. found near the base of peat cores collected in the OCF and Bluefish Basin (Ovenden, 1982; Lauriol et al., 2009) raise the possibility that these willow- and sedge-dominated plant communities have been co-occurring on drained lake basins since the early Holocene. 
TABLE 1. Pair-wise comparisons of plant community composition between field sites using the ANOSIM procedure. U. Shrub $=$ Upright Shrub and D. Shrub = Dwarf Shrub. $\mathrm{R}_{A N O S I M}$ values higher than 0.75 indicate well-separated groups, values between 0.5 and 0.75 describe overlapping but distinguishable groups, and values less than 0.25 represent groups that cannot be separated (Clarke and Gorley, 2001).

\begin{tabular}{|c|c|c|c|c|c|c|c|}
\hline & Basin 5 & Basin 4 & Basin 3 & Basin 2 & Basin 1 & D. Shrub & U. Shrub \\
\hline Woodland & 0.52 & 0.85 & 0.906 & 0.999 & 0.919 & 0.857 & 0.909 \\
\hline U. Shrub & 0.691 & 0.934 & 0.935 & 0.999 & 0.866 & 0.394 & \\
\hline D. Shrub & 0.693 & 0.918 & 0.925 & 0.999 & 0.923 & & \\
\hline Basin 1 & 0.713 & 0.807 & 0.705 & 0.955 & & & \\
\hline Basin 2 & 0.844 & 0.291 & 0.412 & & & & \\
\hline Basin 3 & 0.393 & 0.152 & & & & & \\
\hline Basin 4 & 0.508 & & & & & & \\
\hline
\end{tabular}

TABLE 2. Results of the SIMPER analysis characterizing similarity in community composition at the sites sampled in this study. The table shows the top five species (or species groups) that make the greatest contribution to the between-group Bray-Curtis similarity for each vegetation type. The mean cover (untransformed) of each species is shown in the second column.

\begin{tabular}{|c|c|c|c|c|c|}
\hline Site type / Species & Mean cover $(\%)$ & Mean similarity & $\mathrm{SD}$ & Percent contribution & Cumulative similarity \\
\hline \multicolumn{6}{|c|}{ Woodland $($ Mean similarity $=61.09)$} \\
\hline Moss & 35.4 & 12.96 & 3.94 & 21.21 & 21.21 \\
\hline Ledum decumbens & 7.9 & 8.71 & 6.30 & 14.25 & 35.46 \\
\hline Vaccinium uliginosum & 9.9 & 7.87 & 2.11 & 12.89 & 48.35 \\
\hline Eriophorum vaginatum & 4.8 & 4.92 & 2.18 & 8.05 & 56.39 \\
\hline Arctostaphylos rubra & 4.8 & 4.05 & 1.13 & 6.63 & 63.03 \\
\hline \multicolumn{6}{|c|}{ Dwarf shrubland $($ Mean similarity $=65.56)$} \\
\hline Ledum decumbens & 27.7 & 14.76 & 2.58 & 22.51 & 22.51 \\
\hline Fruiticose lichen & 16.5 & 10.00 & 1.48 & 15.26 & 37.77 \\
\hline Rubus chamaemorus & 7.2 & 8.85 & 5.72 & 13.50 & 51.27 \\
\hline Betula glandulosa & 10.6 & 8.18 & 1.49 & 12.48 & 63.75 \\
\hline Vaccinium vitis-idaea & 10.6 & 8.16 & 1.74 & 12.45 & 76.20 \\
\hline \multicolumn{6}{|c|}{ Shrubland $($ Mean similarity $=62.95)$} \\
\hline Ledum decumbens & 38.6 & 19.83 & 3.26 & 31.50 & 31.50 \\
\hline Vaccinium vitis-idaea & 32.3 & 18.79 & 5.62 & 29.85 & 61.34 \\
\hline Betula glandulosa & 18.1 & 9.45 & 1.25 & 15.01 & 76.35 \\
\hline Moss & 8.1 & 7.99 & 1.33 & 12.69 & 89.04 \\
\hline Eriophorum russeolum & 9.4 & 2.66 & 0.48 & 4.23 & 93.27 \\
\hline \multicolumn{6}{|c|}{ Drained basin $1($ Mean similarity $=50.50)$} \\
\hline Moss & 19.0 & 16.16 & 1.79 & 32.01 & 32.01 \\
\hline Eriophorum russeolum & 21.0 & 11.64 & 1.02 & 23.05 & 55.06 \\
\hline Carex aquatilis & 6.8 & 6.70 & 0.83 & 13.27 & 68.32 \\
\hline Senecio congestus & 4.7 & 4.48 & 0.80 & 8.88 & 77.20 \\
\hline Salix spp. & 1.5 & 2.22 & 0.63 & 4.40 & 81.60 \\
\hline \multicolumn{6}{|c|}{ Drained basin $2($ Mean similarity $=72.64)$} \\
\hline Equisetum arvense & 58.6 & 42.24 & 3.08 & 58.16 & 58.16 \\
\hline Salix spp. & 25.9 & 24.98 & 1.74 & 34.39 & 92.55 \\
\hline \multicolumn{6}{|c|}{ Drained basin $3($ Mean similarity $=53.12)$} \\
\hline Salix spp. & 33.6 & 20.79 & 1.85 & 39.13 & 39.13 \\
\hline Carex aquatilis & 21.6 & 13.50 & 0.89 & 25.42 & 64.55 \\
\hline Equisetum arvense & 20.1 & 8.97 & 1.00 & 16.88 & 81.43 \\
\hline Moss & 9.6 & 7.02 & 0.92 & 13.22 & 94.65 \\
\hline \multicolumn{6}{|c|}{ Drained basin $4($ Mean similarity $=57.56)$} \\
\hline Salix spp. & 40.3 & 23.38 & 1.79 & 40.61 & 40.61 \\
\hline Equisetum arvense & 28.3 & 18.42 & 1.59 & 31.99 & 72.61 \\
\hline Moss & 12.7 & 7.41 & 1.05 & 12.88 & 85.49 \\
\hline Carex aquatilis & 3.4 & 3.52 & 0.63 & 6.11 & 91.60 \\
\hline \multicolumn{6}{|c|}{ Drained basin $5($ Mean similarity $=51.75)$} \\
\hline Moss & 50.9 & 20.87 & 2.76 & 40.32 & 40.32 \\
\hline Salix spp. & 16.8 & 13.24 & 1.81 & 25.58 & 65.90 \\
\hline Carex aquatilis & 14.1 & 4.30 & 0.43 & 8.31 & 74.21 \\
\hline Ledum decumbens & 5.8 & 2.44 & 0.62 & 4.71 & 83.89 \\
\hline Vaccinium vitis-idaea & 6.0 & 2.44 & 0.62 & 4.71 & 83.89 \\
\hline
\end{tabular}

\section{Long-term Succession}

Although willow was widespread on the oldest drained lake basin sampled, it is unlikely that these populations will persist indefinitely. Decreases in willow height and stem density and increases in the density of dead stems on older drained basins suggest that intense intraspecific competition drives self-thinning in these stands. Self-thinning has been widely observed in several species of willow cultivated at high density (Verwijst, 1996; Bullard et al., 2002). It is possible that open-canopy willow communities will persist on older drained lake basins, but several lines of evidence 
TABLE 3. Pair-wise comparisons of plant community composition among the clusters created using the hierarchical cluster analysis. $\mathrm{R}_{A N O S I M}$ values higher than 0.75 indicate well-separated groups, values between 0.5 and 0.75 describe overlapping but distinguishable groups, and values less than 0.25 represent groups that cannot be separated (Clarke and Gorley, 2001).

\begin{tabular}{lccc}
\hline \hline & Cluster D & Cluster C & Cluster B \\
\hline Cluster A & 0.946 & 0.866 & 0.694 \\
Cluster B & 0.846 & 0.922 & \\
Cluster C & 0.812 & & \\
\hline \hline
\end{tabular}

suggest that these assemblages will be replaced by other plant communities. Lakes in the OCF that drained before the earliest air photos tend to be dominated by dwarf shrubs or mosses. Although the age of these basins is unknown, the fact that shrub thickets are uncommon on these older surfaces strongly suggests that tall willow communities are seral. This suggestion is consistent with the vegetation transitions described by Ovenden (1982) using a peat core collected in the southern part of the OCF. At that site, the terrestrialization of a shallow lake involved transitions (over 11000 years) from 1) a wet sedge-shrub community, to 2) a wet sedge fen, to 3) a shallow Sphagnum bog, and ultimately, to 4) a dwarf shrub heath.

It is likely that the willow thickets on drained lake basins in the OCF will be replaced by later seral vegetation as is the case with many shrub-dominated communities in temperate and boreal ecosystems (Foote, 1983; Morneau and Payette, 1989; Chapin et al., 1994). However, it is unclear whether the willow-sedge mosaics described here will transition to the tussock and dwarf shrub communities that currently dominate older drained basins in the OCF, Alaskan Coastal Plain, and Tuktoyaktuk Coastlands (Billings and Peterson, 1980; Ovenden, 1986; Jones et al., 2012) or will follow another successional trajectory in response to the warmer
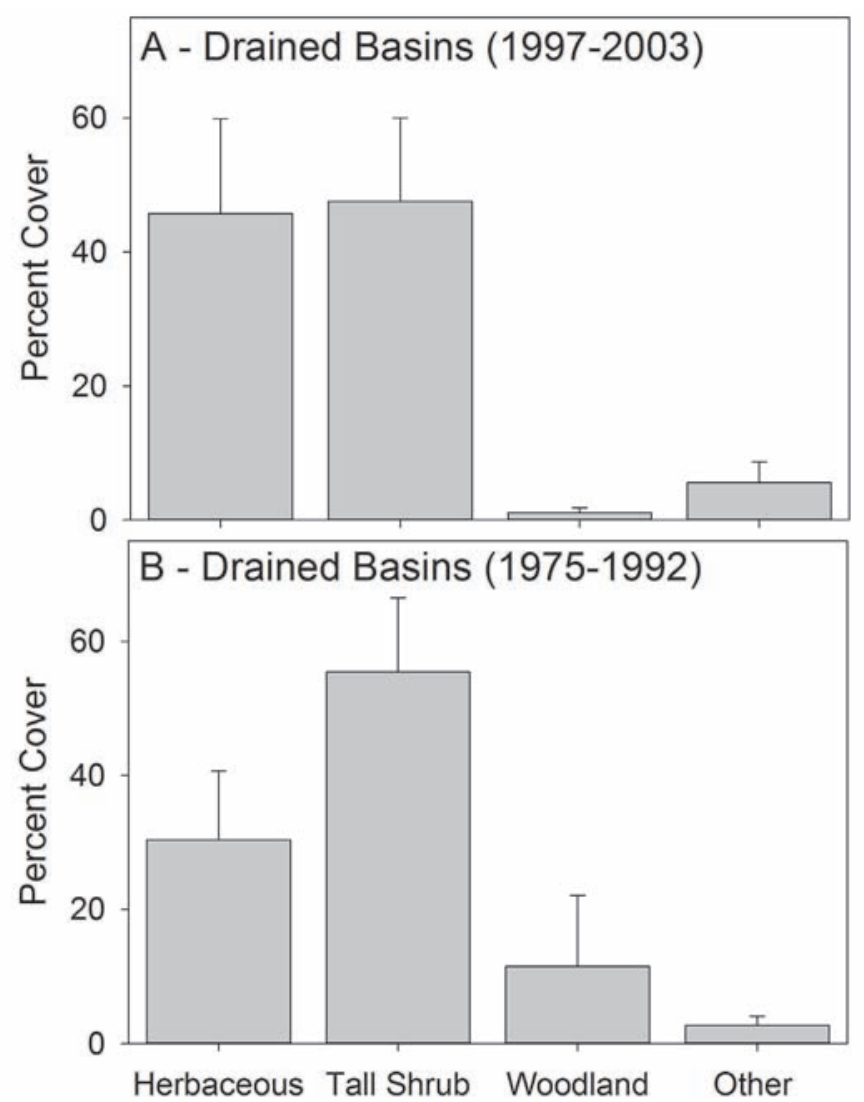

FIG. 6. Vegetation structure at drained lake basins in two age classes: (A) 1997-2003 (5-11 years old) and (B) 1975-1992 (16-33 years old). Bars show the mean cover of major functional groups based on a land cover classification derived from SPOT satellite imagery. Error bars show the $95 \%$ confidence intervals of the mean.

and wetter climate in the OCF today (Porter and Pisaric, 2011; Lantz and Turner, 2015). The presence of spruce and birch saplings, dwarf shrubs, and hydrophilic sedges on the older basins sampled indicates that longer-term succession

TABLE 4. Results of the SIMPER analysis characterizing similarity in community composition in the groups created using the hierarchical cluster analysis of drained lakes. The table shows the top five species (or species groups) that make the greatest contribution to the between-group Bray-Curtis similarity for each cluster shown on Figure 4. The mean cover (untransformed) of each species is shown in the second column.

\begin{tabular}{|c|c|c|c|c|c|}
\hline Site type / Species & Mean cover $(\%)$ & Mean similarity & $\mathrm{SD}$ & Percent contribution & Cumulative similarity \\
\hline \multicolumn{6}{|l|}{ Cluster A (54.77) } \\
\hline Moss & 54.7 & 23.45 & 4.42 & 42.81 & 42.81 \\
\hline Salix spp. & 18.0 & 13.72 & 2.10 & 25.05 & 67.87 \\
\hline Equisetum arvense & 4.6 & 3.17 & 0.67 & 5.79 & 73.65 \\
\hline Arctostaphylos rubra & 4.4 & 2.59 & 0.59 & 4.73 & 78.38 \\
\hline Ledum decumbens & 5.6 & 2.54 & 0.57 & 4.64 & 83.02 \\
\hline \multicolumn{6}{|l|}{ Cluster B (60.41) } \\
\hline Salix spp. & 22.8 & 26.88 & 2.71 & 44.49 & 44.49 \\
\hline Equisetum arvense & 28.5 & 22.35 & 1.45 & 36.99 & 81.48 \\
\hline Carex aquatilis & 8.0 & 6.51 & 0.76 & 10.78 & 92.27 \\
\hline \multicolumn{6}{|l|}{ Cluster C (54.86) } \\
\hline Moss & 19.1 & 19.29 & 3.19 & 35.15 & 35.15 \\
\hline Eriophorum russeolum & 18.4 & 11.49 & 1.05 & 20.94 & 56.09 \\
\hline Carex aquatilis & 6.6 & 7.99 & 0.97 & 14.57 & 70.66 \\
\hline Senecio congestus & 4.6 & 5.35 & 0.93 & 9.75 & 80.41 \\
\hline Salix spp. & 1.4 & 2.65 & 0.72 & 4.84 & 85.25 \\
\hline \multicolumn{6}{|l|}{ Cluster D (68.87) } \\
\hline Carex aquatilis & 58.0 & 65.08 & 2.76 & 94.50 & 94.50 \\
\hline
\end{tabular}



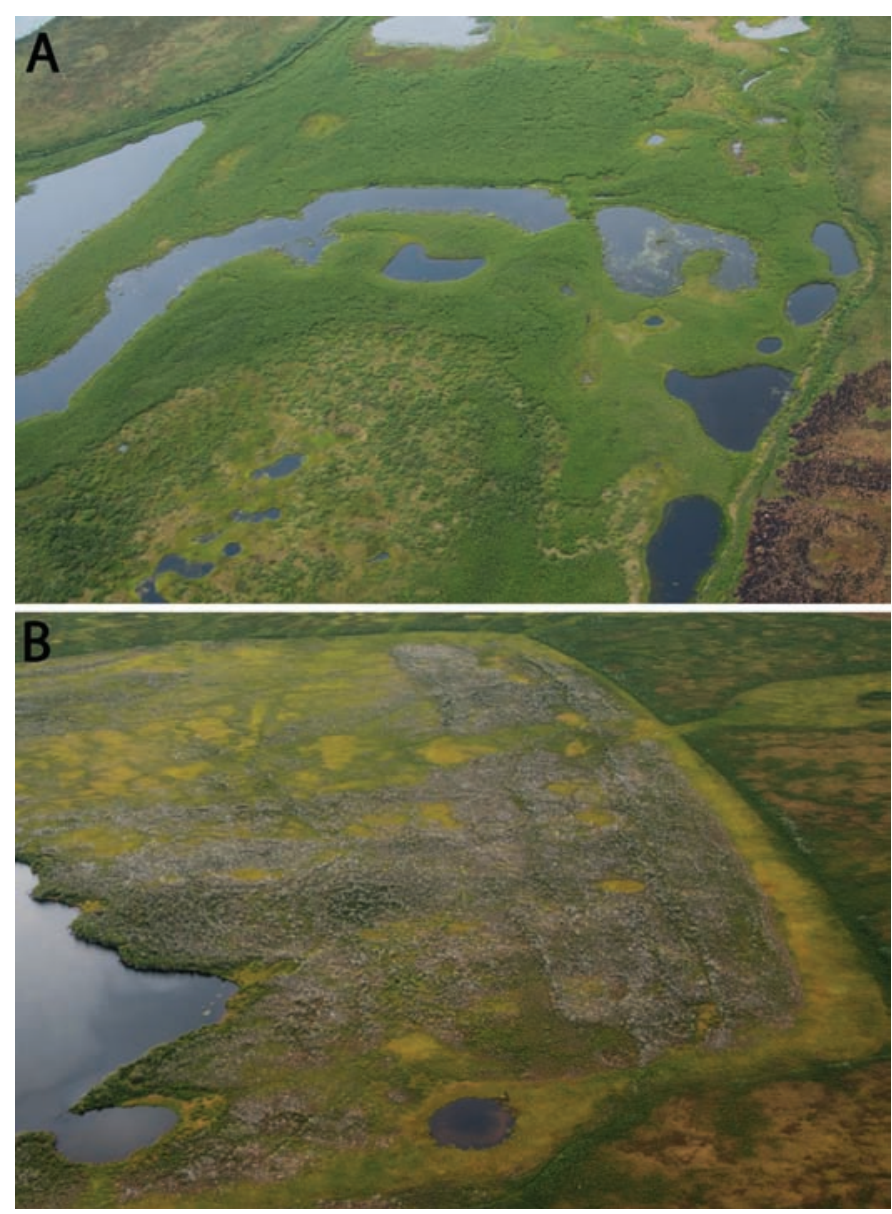

FIG. 7. Oblique aerial photos of two partially drained lakes in the Old Crow Flats. The lake shown in (A) drained in $1977\left(68^{\circ} 00^{\prime} 34^{\prime \prime} \mathrm{N}, 140^{\circ} 28^{\prime} 16^{\prime \prime} \mathrm{W}\right)$ and the lake shown in (B) drained sometime between 1950 and $1972\left(68^{\circ} 13^{\prime} 59^{\prime \prime} \mathrm{N}\right.$, $\left.139^{\circ} 17^{\prime} 29^{\prime \prime} \mathrm{W}\right)$. The younger lake (A) is dominated by dense productive willow, while the older surface (B) is covered in willow stands with numerous dead stems (grey-white areas). The willow stands in both images are interspersed with sedge sward (brown to olive green areas).

on drained lake basins may result in the development of highly heterogeneous plant communities. At present, a limited understanding of Arctic and Subarctic succession on centennial and millennial time scales limits our ability to predict the combined impact of altered disturbance regimes and climate change on long-term vegetation structure (Johnstone and Chapin, 2003; Lantz et al., 2009; Cameron and Lantz, 2017). To better characterize past and current vegetation dynamics and to develop a predictive framework, ongoing monitoring should be combined with research employing longer chronosequences and paleoecological reconstructions based on multiple sites.

\section{Significance}

Lantz and Turner (2015) showed that catastrophic lake drainages between 1952 and 2010 increased the terrestrial surface of the OCF by 2896 ha $(\sim 1 \%$ of the terrestrial study area). The rapid development of shrub thickets interspersed with sedge sward in these areas will increase landscape heterogeneity and affect several significant

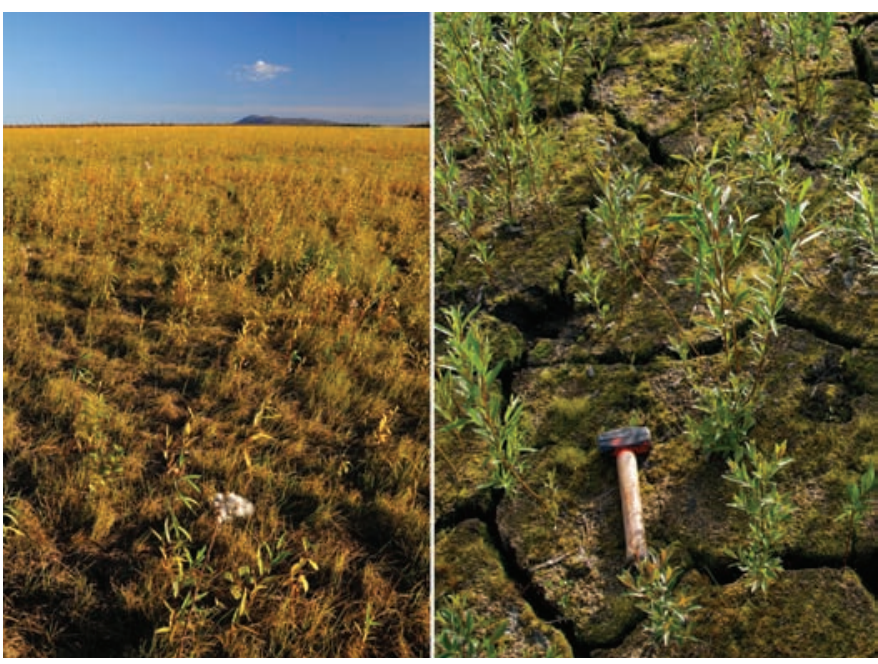

FIG. 8. Extensive willow cover on Zelma Lake ( $\left.67^{\circ} 55^{\prime} 16^{\prime \prime} \mathrm{N}, 139^{\circ} 58^{\prime} 01^{\prime \prime} \mathrm{W}\right)$ two years after catastrophic drainage in 2007. The mallet shown at right is approximately $30 \mathrm{~cm}$ long. Photos: Kevin Turner.

ecosystem processes. Recent research in the OCF suggests that vegetation development on drained lake basins will have a positive impact on moose populations (Clarke et al., 2017). Conversely, ongoing community-based research in the OCF indicates that the residual ponds that remain after lake drainage are no longer suitable muskrat habitat (J. Brammer, pers. comm. 2016).

It is likely that the development of willow thickets on drained lake basins will alter the hydrology of these basins by increasing winter snow capture. Mackay and Burn (2002a) reported that vegetation development following the experimental drainage of Lake Illisarvik increased snow entrapment across the former basin. This observation is consistent with numerous studies showing that tall vegetation increases snow capture (Pomeroy et al., 1997; McFadden et al., 2001; Sturm et al., 2001). Observations made at Illisarvik show that increased snow capture in drained lake basins can increase permafrost temperatures (Mackay and Burn, 2002a). At several drained basins in other parts of the Tuktoyaktuk Coastlands, tall willows are associated with ground temperatures (at $1 \mathrm{~m}$ depth) that remain above zero for the duration of the winter (Kokelj et al., 2017).

Increases in the frequency of lake drainage are also likely to influence regional carbon flux. Peat formation in drained lake basins over the course of the Holocene has created a large below-ground carbon stock (Vardy et al., 1997; Hinkel et al., 2003; Jones et al., 2012). Jones et al (2012) estimated that in a $515 \mathrm{~km}^{2}$ area of northern Alaska, carbon stocks likely exceed $6.4-6.6 \mathrm{Tg}$ of organic C. Field sampling south of Barrow, Alaska, confirms that basins of various age remain net carbon sinks during the summer (Zona et al., 2010). This finding suggests that more frequent lake drainage will increase localized carbon storage and may offset losses of soil carbon caused by other forms of thermokarst (Jones et al., 2012). However, to my knowledge, no studies have explored carbon flux on drained basins 
dominated by upright shrubs. Evidence that snow capture increases winter ground temperatures in drained lake basins dominated by tall willows raises the possibility that carbon emission from warm soils may offset any carbon sequestered by vegetation development at these sites (Wang et al., 2011). Future investigations should explore carbon fluxes on drained lake basins in regions where succession leads to the development of shrub thickets.

\section{ACKNOWLEDGEMENTS}

This research was supported by the Government of Canada International Polar Year Program, the Natural Sciences and Engineering Research Council of Canada, and the Canada Foundation for Innovation. Erika Tizya provided excellent assistance in the field in the summers of 2008 and 2009. Tracy Bruce, Sonja Foss, Sarah Gergel, Shel Graupe, Jim Hawkings, Kendra Holt, Pascale Roy-Léveillée, and Stan Njootli Sr. provided valuable assistance with planning and logistics. I would also like to thank the Vuntut Gwitch'in land users who contributed to the Yeendoo Nanh Nakhweenjit K'at r'ahanaht yaa project and the Vuntut Gwitchin First Nation for supporting this initiative.

\section{REFERENCES}

Arp, C.D., Jones, B.M., Schmutz, J.A., Urban, F.E., and Jorgenson, M.T. 2010. Two mechanisms of aquatic and terrestrial habitat change along an Alaskan Arctic coastline. Polar Biology 33(12):1629-1640. https://doi.org/10.1007/s00300-010-0800-5

Billings, W.D., and Peterson, K.M. 1980. Vegetational change and ice-wedge polygons through the thaw-lake cycle in Arctic Alaska. Arctic and Alpine Research 12(4):413-432. https://doi.org/10.2307/1550492

Bret-Harte, M.S., Mack, M.C., Shaver, G.R., Huebner, D.C., Johnston, M., Mojica, C.A., Pizano, C., and Reiskind, J.A. 2013. The response of Arctic vegetation and soils following an unusually severe tundra fire. Philosophical Transactions of the Royal Society B 368(1624): 20120490.

https://doi.org/10.1098/rstb.2012.0490

Bullard, M.J., Mustill, S.J., McMillan, S.D., Nixon, P.M.I., Carver, P., and Britt, C.P. 2002. Yield improvements through modification of planting density and harvest frequency in short rotation coppice Salix spp.-1. Yield response in two morphologically diverse varieties. Biomass \& Bioenergy 22(1):15-25.

https://doi.org/10.1016/S0961-9534(01)00054-X

Burn, C.R., and Kokelj, S.V. 2009. The environment and permafrost of the Mackenzie Delta area. Permafrost and Periglacial Processes 20(2):83-105.

https://doi.org/10.1002/ppp.655
Cameron, E.A., and Lantz, T.C. 2017. Persistent changes to ecosystems following winter road construction and abandonment in an area of discontinuous permafrost, Nahanni National Park Reserve, Northwest Territories, Canada. Arctic, Alpine, and Antarctic Research 49(2):259-276.

Cannell, M.G.R., Sheppard, L.J., and Milne, R. 1988. Light use efficiency and woody biomass production of poplar and willow. Forestry 61(2):125-136. https://doi.org/10.1093/forestry/61.2.125

Chapin, F.S., III, Walker, L.R., Fastie, C.L., and Sharman, L.C. 1994. Mechanisms of primary succession following deglaciation at Glacier Bay, Alaska. Ecological Monographs 64(2):149- 175 .

https://doi.org/10.2307/2937039

Chapin, F.S., III, McGuire, A.D., Randerson, J., Pielke, R., Sr., Baldocchi, D., Hobbie, S.E., Roulet, N., et al. 2000. Arctic and boreal ecosystems of western North America as components of the climate system. Global Change Biology 6(S1):211 - 223. https://doi.org/10.1046/j.1365-2486.2000.06022.x

Clarke, H., Cooley, D., Humphries, M., Landry-Cuerrier, M., and Lantz, T. 2017. Summer habitat selection by moose on the Old Crow Flats. Report MR-17-01. Whitehorse, Yukon: Yukon Fish and Wildlife Branch.

Clarke, K.R., and Gorley, R.N. 2001. PRIMER v5: User manual/ tutorial. Plymouth, United Kingdom: PRIMER-E.

Cody, W.J. 2000. Flora of the Yukon Territory, 2nd ed. Ottawa: NRC Research Press.

Environment Canada. 2016. Canadian climate normals: 1981-2010 climate normals \& averages.

http://climate.weather.gc.ca/climate_normals/index_e.html

Foote, M.J. 1983. Classification, description, and dynamics of plant communities after fire in the taiga of interior Alaska. Research Paper PNW-307. Portland, Oregon: U.S. Department of Agriculture, Forest Service, Pacific Northwest Forest and Range Experiment Station.

http://www.fs.fed.us/pnw/publications/pnw_rp307/pnw_ rp307a.pdf

Handa, I.T., Harmsen, R., and Jefferies, R.L. 2002. Patterns of vegetation change and the recovery potential of degraded areas in a coastal marsh system of the Hudson Bay lowlands. Journal of Ecology 90(1):86-99.

https://doi.org/10.1046/j.0022-0477.2001.00635.x

Higuera, P.E., Brubaker, L.B., Anderson, P.M., Brown, T.A., Kennedy, A.T., and Hu, F.S. 2008. Frequent fires in ancient shrub tundra: Implications of paleorecords for Arctic environmental change. PLOS ONE 3(3): e0001744.

https://doi.org/10.1371/journal.pone.0001744

Hinkel, K.M., Eisner, W.R., Bockheim, J.G., Nelson, F.E., Peterson, K.M., and Dai, X. 2003. Spatial extent, age, and carbon stocks in drained thaw lake basins on the Barrow Peninsula, Alaska. Arctic, Antarctic, and Alpine Research 35(3):291 - 300. https://doi.org/10.1657/1523-0430(2003)035[0291:SEAACS]2. $0 . \mathrm{CO} ; 2$

Holroyd, P., and Retzer, H. 2005. A peak into the future: Potential landscape impacts of gas development in northern Canada. Drayton Valley, Alberta: The Pembina Institute.

http://cpaws.org/uploads/pubs/report_peak-into-future.pdf 
Johnstone, J.F., and Chapin, F.S. 2003. Non-equilibrium succession dynamics indicate continued northern migration of lodgepole pine. Global Change Biology 9(10):1401 - 1409. https://doi.org/10.1046/j.1365-2486.2003.00661.x

Johnstone, J.F., and Kokelj, S.V. 2008. Environmental conditions and vegetation recovery at abandoned drilling mud sumps in the Mackenzie Delta region, Northwest Territories, Canada. Arctic 61(2):199-211. https://doi.org/10.14430/arctic35

Jones, B.M., Grosse, G., Arp, C.D., Jones, M.C., Walter Anthony, K.M., and Romanovsky, V.E. 2011. Modern thermokarst lake dynamics in the continuous permafrost zone, northern Seward Peninsula, Alaska. Journal of Geophysical Research: Biogeosciences 116(G2), G00M03. https://doi.org/10.1029/2011JG001666

Jones, M.C., Grosse, G., Jones, B.M., and Anthony, K.W. 2012. Peat accumulation in drained thermokarst lake basins in continuous, ice-rich permafrost, northern Seward Peninsula, Alaska. Journal of Geophysical Research: Biogeosciences 117(G2), G00M07. https://doi.org/10.1029/2011JG001766

Jorgenson, M.T., and Shur, Y. 2007. Evolution of lakes and basins in northern Alaska and discussion of the thaw lake cycle. Journal of Geophysical Research: Earth Surface 112(F2), F02S17. https://doi.org/10.1029/2006JF000531

Kasischke, E.S., and Turetsky, M.R. 2006. Recent changes in the fire regime across the North American boreal region-Spatial and temporal patterns of burning across Canada and Alaska. Geophysical Research Letters 33(9), L09703. https://doi.org/10.1029/2006GL025677

Kemper, J.T., and Macdonald, S.E. 2009a. Directional change in upland tundra plant communities 20-30 years after seismic exploration in the Canadian Low-Arctic. Journal of Vegetation Science 20(3):557-567. https://doi.org/10.1111/j.1654-1103.2009.01069.x

- 2009b. Effects of contemporary winter seismic exploration on Low Arctic plant communities and permafrost. Arctic, Antarctic, and Alpine Research 41(2):228-237. https://doi.org/10.1657/1938-4246-41.2.228

Kokelj, S.V., Lantz, T.C., Solomon, S., Pisaric, M.F.J., Keith, D., Morse, P., Thienpont, J.R., Smol, J.P., and Esagok, D. 2012. Using multiple sources of knowledge to investigate northern environmental change: Regional ecological impacts of a storm surge in the outer Mackenzie Delta, N.W.T. Arctic 65(3):257-272. https://doi.org/10.14430/arctic4214

Kokelj, S.V., Lacelle, D., Lantz, T.C., Tunnicliffe, J., Malone, L., Clark, I.D., and Chin, K.S. 2013. Thawing of massive ground ice in mega slumps drives increases in stream sediment and solute flux across a range of watershed scales. Journal of Geophysical Research: Earth Surface 118(2):681-692. https://doi.org/10.1002/jgrf.20063
Kokelj, S.V., Palmer, M.J., Lantz, T.C., and Burn, C.R. 2017. Ground temperatures and permafrost warming from forest to tundra, Tuktoyaktuk Coastlands and Anderson Plain, NWT, Canada. Permafrost and Perigalcial Processes. Published online 23 March 2017. https://doi.org/10.1002/ppp.1934

Labrecque, S., Lacelle, D., Duguay, C.R., Lauriol, B., and Hawkings, J. 2009. Contemporary (1951-2001) evolution of lakes in the Old Crow Basin, northern Yukon, Canada: Remote sensing, numerical modeling, and stable isotope analysis. Arctic 62(2):225-238.

https://doi.org/10.14430/arctic134

Lantz, T.C., and Turner, K.W. 2015. Changes in lake area in response to thermokarst processes and climate in Old Crow Flats, Yukon. Journal of Geophysical Research: Biogeosciences 120(3):513-524. https://doi.org/10.1002/2014JG002744

Lantz, T.C., Kokelj, S.V., Gergel, S.E., and Henry, G.H.R. 2009. Relative impacts of disturbance and temperature: Persistent changes in microenvironment and vegetation in retrogressive thaw slumps. Global Change Biology 15(7):1664-1675. https://doi.org/10.1111/j.1365-2486.2009.01917.x

Lantz, T.C., Gergel, S.E., and Henry, G.H.R. 2010. Response of green alder (Alnus viridis subsp. fruticosa) patch dynamics and plant community composition to fire and regional temperature in north-western Canada. Journal of Biogeography 37(8):1597- 1610 . https://doi.org/10.1111/j.1365-2699.2010.02317.x

Lantz, T.C., Marsh, P., and Kokelj, S.V. 2013. Recent shrub proliferation in the Mackenzie Delta uplands and microclimatic implications. Ecosystems 16(1):47-59. https://doi.org/10.1007/s10021-012-9595-2

Lantz, T.C., Kokelj, S.V., and Fraser, R.H. 2015. Ecological recovery in an Arctic delta following widespread saline incursion. Ecological Applications 25(1):172-185. https://doi.org/10.1890/14-0239.1

Lauriol, B., Lacelle, D., Labrecque, S., Duguay, C.R., and Telka, A. 2009. Holocene evolution of lakes in the Bluefish Basin, northern Yukon, Canada. Arctic 62(2):212-224. https://doi.org/10.14430/arctic133

Legendre, P., and Legendre, L. 1998. Numerical ecology, 2nd ed. Developments in Environmental Modelling 20. New York: Elsevier Science.

Lewkowicz, A.G., and Harris, C. 2005. Frequency and magnitude of active-layer detachment failures in discontinuous and continuous permafrost, northern Canada. Permafrost and Periglacial Processes 16(1):115-130.

https://doi.org/10.1002/ppp.522

Mackay, J.R. 1988. Catastrophic lake drainage, Tuktoyaktuk Peninsula area, District of Mackenzie. In: Current Research, Part D, Interior Plains and Arctic Canada, Paper 88-1D. Ottawa: Geological Survey of Canada. 83-90.

Mackay, J.R., and Burn, C.R. 2002a. The first 20 years (19781979 to 1998-1999) of active-layer development, Illisarvik experimental drained lake site, western Arctic coast, Canada. Canadian Journal of Earth Sciences 39(11):1657-1674. https://doi.org/10.1139/e02-068 
2002b. The first 20 years (1978-1979 to 1998-1999) of ice-wedge growth at the Illisarvik experimental drained lake site, western Arctic coast, Canada. Canadian Journal of Earth Sciences 39(1):95-111. https://doi.org/10.1139/E01-048

Marsh, P., Russell, M., Pohl, S., Haywood, H., and Onclin, C. 2009. Changes in thaw lake drainage in the western Canadian Arctic from 1950 to 2000. Hydrological Processes 23(1):145 - 158. https://doi.org/10.1002/hyp.7179

McFadden, J.P., Liston, G.E., Sturm, M., Pielke, R.A., Sr., and Chapin, F.S., III. 2001. Interactions of shrubs and snow in Arctic tundra: Measurements and models. In: Soil-vegetationatmosphere transfer schemes and large-scale hydrological models: Proceedings of a symposium held during the Sixth IAHS Scientific Assembly, 18-27 July 2001, Maastricht, The Netherlands. IAHS Publication No. 270:317-324.

Morneau, C., and Payette, S. 1989. Postfire lichen-spruce woodland recovery at the limit of the boreal forest in northern Quebec. Canadian Journal of Botany 67(9):2770-2782. https://doi.org/10.1139/b89-357

Ovenden, L. 1982. Vegetation history of a polygonal peatland, northern Yukon. Boreas 11(3):209-224.

https://doi.org/10.1111/j.1502-3885.1982.tb00715.x

___ 1986. Vegetation colonizing the bed of a recently drained thermokarst lake (Illisarvik), Northwest Territories. Canadian Journal of Botany 64(11):2688-2692. https://doi.org/10.1139/b86-354

Parks Canada, Vuntut Gwitchin Government and North Yukon Renewable Resources Council. 2010. Vuntut National Park of Canada management plan. Yellowknife, Northwest Territories: Parks Canada. http://www.pc.gc.ca/eng/pn-np/yt/vuntut/plan/res-sum.aspx

Pomeroy, J.W., Marsh, P., and Gray, D.M. 1997. Application of a distributed blowing snow model to the Arctic. Hydrological Processes 11(11):1451-1464.

https://doi.org/10.1002/(SICI)1099-1085(199709)11: 11<1451::AID-HYP449>3.0.CO;2-Q

Porter, T.J., and Pisaric, M.F.J. 2011. Temperature-growth divergence in white spruce forests of Old Crow Flats, Yukon Territory, and adjacent regions of northwestern North America. Global Change Biology 17(11):3418-3430.

https://doi.org/10.1111/j.1365-2486.2011.02507.x

R Development Core Team. 2008. R: A language and environment for statistical computing, reference index, version 2.6.2. Vienna, Austria: R Foundation for Statistical Computing. http://softlibre.unizar.es/manuales/aplicaciones/r/fullrefman. pdf

Riordan, B., Verbyla, D., and McGuire, A.D. 2006. Shrinking ponds in subarctic Alaska based on 1950-2002 remotely sensed images. Journal of Geophysical Research: Biogeosciences 111(G4), G04002. https://doi.org/10.1029/2005JG000150
Rocha, A.V., Loranty, M.M., Higuera, P.E., Mack, M.C., Hu, F.S., Jones, B.M., Breen, A.L., Rastetter, E.B., Goetz, S.J., and Shaver, G.R. 2012. The footprint of Alaskan tundra fires during the past half-century: Implications for surface properties and radiative forcing. Environmental Research Letters 7(4), 044039 . https://doi.org/10.1088/1748-9326/7/4/044039

Royal Botanic Gardens, Kew. 2008. Seed information database (SID), version 7.1. Richmond, United Kingdom: Royal Botanic Gardens, Kew.

http://data.kew.org/sid/

Roy-Léveillée, P., and Burn, C.R. 2016. A modified landform development model for the topography of drained thermokarst lake basins in fine-grained sediments. Earth Surface Processes and Landforms 41(11):1504-1520.

https://doi.org/10.1002/esp.3918

Segal, R.A., Lantz, T.C., and Kokelj, S.V. 2016. Acceleration of thaw slump activity in glaciated landscapes of the western Canadian Arctic. Environmental Research Letters 11(3), 034025 . https://doi.org/10.1088/1748-9326/11/3/034025

Smith, C.A.S., Meikle, J.C., and Roots, C.F., eds. 2004. Ecoregions of the Yukon Territory: Biophysical properties of Yukon landscapes. PARC Technical Bulletin 04-01. Summerland, British Columbia: Agriculture and Agri-Food Canada.

http://www.env.gov.yk.ca/animal-habitat/documents/ ecoregions_of_yukon_reduced.pdf

Smith, K.B., Smith, C.E., Forest, S.F., and Richard, A.J. 2007. A field guide to the wetlands of the Boreal Plains ecozone of Canada. Edmonton, Alberta: Ducks Unlimited Canada, Western Boreal Office. http://www.canards.ca/assets/2012/09/fieldguide.pdf?9d7bd4

Smith, L.C., Sheng, Y., MacDonald, G.M., and Hinzman, L.D. 2005. Disappearing Arctic lakes. Science 308(5727):1429. https://doi.org/10.1126/science.1108142

Sturm, M., McFadden, J.P., Liston, G.E., Chapin, F.S., III, Racine, C.H., and Holmgren, J. 2001. Snow-shrub interactions in Arctic tundra: A hypothesis with climatic implications. Journal of Climate 14:336-344.

https://doi.org/10.1175/1520-0442(2001)014<0336:SSIIAT>2.0. $\mathrm{CO} ; 2$

Turner, K.W., Wolfe, B.B., Edwards, T.W.D., Lantz, T.C., Hall, R.I., and Larocque, G. 2014. Controls on water balance of shallow thermokarst lakes and their relations with catchment characteristics: A multi-year, landscape-scale assessment based on water isotope tracers and remote sensing in Old Crow Flats, Yukon (Canada). Global Change Biology 20(5):1585-1603. https://doi.org/10.1111/gcb.12465

Vardy, S.R., Warner, B.G., and Aravena, R. 1997. Holocene climate effects on the development of a peatland on the Tuktoyaktuk Peninsula, Northwest Territories. Quaternary Research 47(1):90-104. https://doi.org/10.1006/qres.1996.1869

Verwijst, T. 1996. Stool mortality and development of a competitive hierarchy in a Salix viminalis coppice system. Biomass and Bioenergy 10(5-6):245-250.

https://doi.org/10.1016/0961-9534(95)00118-2 
Vuntut Gwitchin First Nation, and Smith, S. 2009. People of the Lakes: Stories of our Van Tat Gwich'in Elders/Googwandak Nakhwach'ànjòo Van Tat Gwich'in. Edmonton, Alberta: The University of Alberta Press.

Walker, D.A., Cate, D., Brown, J., and Racine, C. 1987. Disturbance and recovery of Arctic Alaskan tundra terrain: A review of recent investigations. Report 87-11. Hanover, New Hampshire: Cold Regions Research and Engineering Laboratory.

Walker, L.R., and Chapin, F.S. 1986. Physiological controls over seedling growth in primary succession on an Alaskan floodplain. Ecology 67(6):1508-1523. https://doi.org/10.2307/1939082

Wang, T., Ciais, P., Piao, S.L., Ottlé, C., Brender, P., Maignan, F., Arain, A., et al. 2011. Controls on winter ecosystem respiration in temperate and boreal ecosystems. Biogeosciences 8:2009-2025.

https://doi.org/10.5194/bg-8-2009-2011
Wolfe, B.B., Humphries, M.M., Pisaric, M.F.J., Balasubramaniam, A.M., Burn, C.R., Chan, L., Cooley, D., et al. 2011. Environmental change and traditional use of the Old Crow Flats in northern Canada: An IPY opportunity to meet the challenges of the new northern research paradigm. Arctic 64(1):127-135. https://doi.org/10.14430/arctic4092

Zazula, G.D., Duk-Rodkin, A., Schweger, C.E., and Morlan, R.E. 2004. Late Pleistocene chronology of glacial Lake Old Crow and the north-west margin of the Laurentide ice sheet. In: Ehlers, J., and Gibbard, P.L., eds. Quaternary glaciations Extent and chronology Part II: North America. Developments in Quaternary Sciences 2(B):347-362.

https://doi.org/10.1016/S1571-0866(04)80207-0

Zona, D., Oechel, W.C., Peterson, K.M., Clements, R.J., Paw U, K.T., and Ustin, S.L. 2010. Characterization of the carbon fluxes of a vegetated drained lake basin chronosequence on the Alaskan Arctic Coastal Plain. Global Change Biology 16(6): $1870-1882$.

https://doi.org/10.1111/j.1365-2486.2009.02107.x 